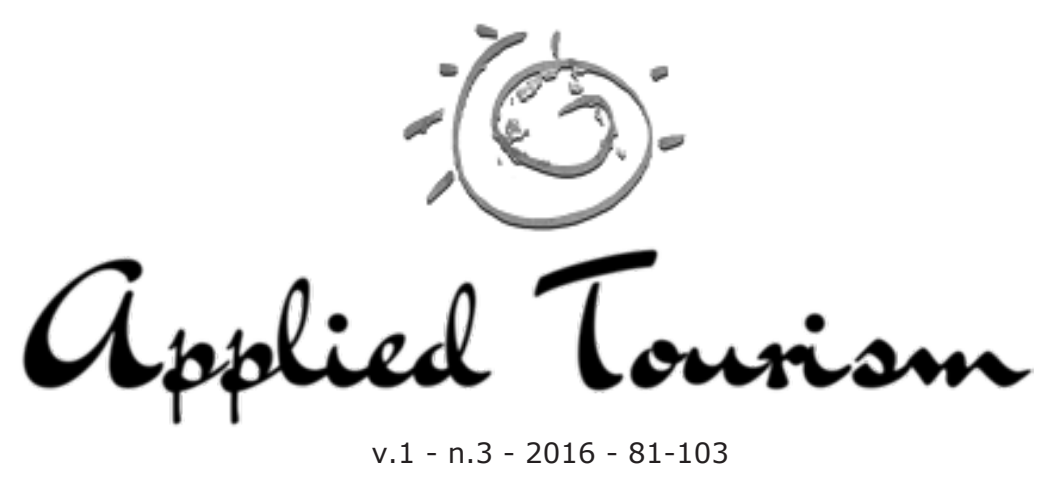

\title{
UNIDADES DE CONSERVAÇÃO E SUSTENTABILIDADE: PLANO DE MANEJO E APLICAÇÃO DA CAPACIDADE DE CARGA NO PARQUE NACIONAL DA LAGOA DO PEIXE (RS)
}

\section{CONSERVATION UNITS AND SUSTAINABILITY: MANAGEMENT PLAN AND APPLICATION OF CARRYING CAPACITY AT LAGOA DO PEIXE NATIONAL PARK (RS - BRAZIL)}

\author{
Rodrigo Hakira Minohara - Mestre em Turismo e Hotelaria (UNIVALI). \\ Universidade Estadual de Mato Grosso do Sul (UEMS). rodrigominohara@gmail.com \\ Rudinei Scaranto Dazzi - Mestre em Turismo e Hotelaria (UNIVALI). Universidade do Vale do \\ Itajaí (UNIVALI). rudiscaranto@gmail.com
}

Alessandra Santos dos Santos - Mestre em Turismo e Hotelaria (UNIVAli). Centro Universitário de Brasília (UniCEUB). alessandra.santos@uniceub.br

Recebido/Received: 08/08/2016 - Aprovação/Approval: 12/12/2016

RESUMO: É crescente a busca do homem pelo contato com o meio ambiente, sobre tudo por meio do turismo. Na década de 1960, houve uma mobilização mundial focada na preservação da natureza e o Brasil seguindo o exemplo, começou a estruturar políticas que garantissem a preservação dos seus ecossistemas. Esse processo acarretou na criação do Sistema Nacional de Unidades de Conservação (SNUC), que veio a regulamentar a visitação desses espaços e a sustentabilidade dos ambientes naturais, por meio de planos de manejo e da adoção de modelos de gestão que respeitem sua capacidade de carga. Considerando tais pressupostos, este artigo visa a composição de uma análise tendo como base o planejamento adotado pela Unidade de Conservação - Parque Nacional da Lagoa do Peixe (RS), local onde foram tratadas as
ABSTRACT: In recent years, man's search for contact with nature has increased, especially through tourism, as a escape from the busy life that the urban environment imposes. As a reflection, in the 1960, there was a world mobilization focused on preserving nature. Brazil, following the example, began to structure policies that ensure the preservation of its ecosystems. This process led to the creation of the National System of Conservation Units (SNUC), which started to regulate visitation of these spaces and the sustainability of natural environments, through management plans and the adoption of management models that respect their carrying capacity. Considering these assumptions, this article aims at the composition of an analysis based on the plan adopted by a Conservation Unit (CU), Lagoa 
questões de manejo e de capacidade de carga para viabilizar o recebimento de visitantes e da promoção da sensibilização para a conservação da biodiversidade. Para desenvolvimento de estudos posteriores, fica a sugestão de realização de pesquisa que englobe todos os parques pertencentes à Região Sul do Brasil, para um possível comparativo em relação ao uso público e à atividade turística.

Palavras-chave: Turismo. Unidades de Conservação. Plano de Manejo.

\section{INTRODUÇÃO}

O Século $X X$, sobretudo no período compreendido a partir da década de 1960, foi marcado por uma mobilização mundial de ativistas, pesquisadores e simpatizantes para a proteção do meio ambiente. Por meio dessa iniciativa, ainda no Século XIX, ocorreu a criação de parques nacionais e reservas ecológicas pelos continentes.

Deste processo, o Brasil passou a fazer parte, tardiamente, várias foram as leis e decretos que conduziram à consolidação, e no ano 2000 o Sistema Nacional de Unidades de Conservação (SNUC) tornou-se Lei no 9.985, visando garantir a proteção dos ecossistemas brasileiros, detentoras de características particulares únicas.

Dos elementos formadores do SNUC, destaca-se a importância do planejamento aplicado àquelas áreas onde a visitação é permitida, viabilizadas por meio de planos de manejos que venham a viabilizar a visitação desses locais e o fomento da atividade turística direcionada à natureza, mas de maneira sustentável, envolvendo a comunidade de entorno e sem causar impactos ao meio natural.

Quando analisado o mercado atual do turismo, é visível que ocorreu um destaque significativo na busca do homem pelo contato com a fauna, a flora e belas paisagens como uma fuga da agitação em que as cidades estão imersas diariamente.

Entretanto, para garantir a integridade desses locais, não necessárias medidas que venham impedir que a natureza sofra danos com o passar do tempo, mesmo estes sendo ocasionados de forma involuntária. Por isso, a aplicação do método de capacidade de carga é vital para a estipulação de parâmetros à visitação, certificando-se que, em longo prazo, os impactos registrados serão aceitáveis e não comprometerão o espaço correspondente. do Peixe National Park (RS-Brazil), where management and capacity issues were dealt with to enable visitors reception and to promote awareness of biodiversity conservation. The original goal of this study was to encompass all parks belonging to the southern region of Brazil, for a possible comparison in relation to public use and tourism activities; however, due to various restrictions, such research remains as a suggestion for the development of later studies.

Key-words: Tourism. Conservation units. Management Plan.

\section{INTRODUCTION}

The 20th century, especially the 1960s, were marked by a worldwide mobilization of activists, researchers and supporters for environment protection. Through this initiative, still in the nineteenth century, the creation of national parks and ecological reserves across continents ocurred.

In this process, where Brazil became a part of later on, there were several laws and decrees that led to consolidation. In 2000 the National System of Conservation Units (SNUG) became Law number 9985 , ensuring the protection of Brazilian ecosystems, holders of unique special features.

From the elements that form the SNUG, the importance of planning, applied to those areas where visitation is allowed, should be highlighted. That is made possible through management plans to facilitate the visits of these sites and the promotion of tourism focused on nature, but so sustainable, involving the community and without any sort of impact to the natural environment.

When analyzing the current tourism market, it is apparent that there was a significant increase in man's search for contact with fauna, flora and beautiful sceneries as an escape from the bustle in which the cities are immersed daily.

However, to ensure the integrity of those sites measures are necessary for preventing nature from suffering damage over time, even if the damage is being caused unintentionally. Therefore, the application of carrying capacity method is vital to the stipulation of parameters for visitors, making sure that in the long term, the recorded impacts are acceptable and will not compromise the corresponding space. 
Tendo como foco esses elementos, foi desenvolvido 0 presente trabalho com 0 objetivo de analisar o plano de manejo e a capacidade de carga, adotados pelo Parque Nacional da Lagoa do Peixe, localizado nas proximidades do município de Mostardas no Estado do Rio Grande do Sul.

O objetivo a que este estudo se propusera, em um primeiro momento, era mais amplo, abarcando todos os parques localizados na Região Sul do Brasil para um comparativo. Contudo, como descrito na metodologia, os fatores limitantes encontrados impediram sua concretização.

Para a abordagem deste trabalho, foram tecidos alicerces teóricos referentes à inserção do turismo no meio natural, sua prática e o planejamento das ações considerando os elementos de sustentabilidade, a criação do SNUC e estipulação das Unidades de Conservação - UCs (focando as análises nos parques nacionais), em relação ao uso público e a aplicação dos planos de manejo e da capacidade de carga desses locais, exemplificados pelo objeto principal de estudo.

\section{PROCEDIMENTOS METODOLÓGICOS}

Para o desenvolvimento do presente artigo, foram elencados referenciais teóricos, compreendendo uma pesquisa de caráter exploratório, amparados por dados primários coletados sobre o plano de manejo do Parque Nacional da Lagoa do Peixe (RS), perante a home page do Instituto Brasileiro do Meio Ambiente e dos Recursos Naturais Renováveis (Ibama, 2002a).

Inicialmente, a pretensão dessa pesquisa era a realização de um paralelo entre os planos de manejos e método de determinação da capacidade de carga dos parques localizados na região sul do Brasil. Para isso, foram estipulados contatos via e-mail com estes parques, afim de obter tais informações. Todavia, dos e-mails enviados, apenas um foi respondido gentilmente por um parque que afirmou ainda não possuir plano de manejo.

Como segunda tentativa de elaboração deste trabalho, foi feita uma busca na internet, principalmente, na home page do Ibama (2002a), para a obtenção dos planos de manejos. Surpreendentemente, apenas o parque utilizado para este artigo, dos localizados na região sul, possuía o plano de manejo para consulta.
Focusing on these elements, this study was developed in order to analyze the management plan and the carrying capacity, adopted by the National Park of Lagoa do Peixe, located near the city of Mostardas in the state of Rio Grande do Sul, Brazil.

The objective of this study, at first was broader, covering all the parks located in southern Brazil for a comparison. However, as described in methodology, limiting factors found prevented its realization.

For the approach of this paper, theoretical foundations regarding the inclusion of tourism in the natural environment were construted, its practice and planning of actions considering the sustainability elements, the creation of SNUC and stipulation of Conservation Units (focusing on the analysis of the National Parks) in relation to public use and implementation of management plans and the carrying capacity of these sites, exemplified by the main object of the study.

\section{METHODOLOGICAL PROCEDURES}

For the development of this article, theoretical framework were listed, comprising an exploratory research, supported by primary data collected on the National Park management plan for the Lagoa do Peixe (RS), regarding the Brazilian Institute of the Environment and Renewable Natural Resources home page (Ibama, 2002a).

Initially, the intention of this research was to carry out a parallel between the management plans and methods for determining the carrying capacity of the parks located in southern Brazil. To this end, contacts were stipulated via email with these parks in order to obtain such information. However, even after sending several emails, only one answered was received by a park saying that they still didn't have a management plan.

As a second attempt to prepare this study, a research was conducted on the internet, especially at Ibama's home page (2002a), to obtain the management plans. Surprisingly, the only Southern park with a management plan avaliable for consultation was the park used for this article.

Given these limitations, it was not possible to achieve the overall objective that this paper intended. Therefore the research focused only on a national park with a very particular feature: its location, since most national parks are located in mountains. 
Diante desses limitantes de pesquisa, não foi possível concretizar o objetivo geral a que este trabalho se propôs, restringindo-se a focar apenas em um parque nacional portador de uma característica bastante particular, sua localização, pois grande parte dos parques nacionais estão localizados em serras.

Para complementar essas informações, bastante reduzidas, que os autores conseguiram obter, foram feitas pesquisas em referenciais teóricos das áreas de turismo, sustentabilidade, meio ambiente, capacidade de carga e Unidades de Conservação para constituir a base teórica deste trabalho, cuja pretensão, em longo prazo, é a busca pelas análises referentes ao seu objetivo original.

Após a reunião e compreensão científica das informações pertinentes à investigação, destaca-se a importância do turismo na preservação da biodiversidade e manutenção das Unidades de Conservação, porém, planejados de forma sustentável e respeitando o fluxo que o espaço pode suportar sem causar impactos.

\section{O SISTEMA NACIONAL DE UNIDADES DE CONSERVAÇÃO - SNUC}

O Sistema Nacional de Unidades de Conservação (SNUC), criado por meio da Lei no 9.985, de 18 de julho de 2000, foi a exemplificação concreta das preocupações do país em relação à preservação dos seus recursos naturais.

Por meio do SNUC, foi viabilizada a visitação desses locais por meio de diretrizes que vieram garantir a integridade do ambiente, sua fauna e flora, em face da busca dos indivíduos, muitas vezes tendo como veículo o turismo, pelo contato com a natureza.

Entretanto, contido no pano de fundo do SNUC, existe uma longa trajetória galgada pela formulação de várias políticas públicas que determinaram sua criação. De acordo com Soawinski (1997), era importante o estabelecimento de uma rede de áreas protegidas, salientada desde o início do Século $X X$, para que ocorresse a criação de parques e reservas por parte do poder público, em vários níveis, refletindo os esforços empregados na proteção dos ecossistemas e biomas brasileiros.

O caminho, percorrido por tais políticas, foi esboçado pelas ementas de leis e decretos
To add-on the few information authors were able to obtain, research has been done on theoretical frameworks from the areas of tourism, sustainability, environment, carrying capacity and conservation units to form the theoretical basis of this study, whose long term intentions it is the search for the analysis related to its original purpose.

After scientific understanding and gathering of relevant information to the research, the importance of tourism in the conservation of biodiversity and maintenance of Conservation Units should be highlighted. However, planned in a sustainable way, respecting the flow capacity for the space without causing impacts.

\section{THE NATIONAL CONSERVATION UNITS SYSTEM - SNUC}

The National System of Conservation Units (SNUC), created by Law number 9.985, from July $18^{\text {th }} 2000$, was the concrete exemplification of the country's concerns regarding the conservation of its natural resources.

Through SNUC, it was made possible to visit these places through guidelines that came to ensure environmental integrity, its fauna and flora, due to the search of individuals, often having as vehicle the tourism for nature contact.

However, contained in the background of SNUC, there is a long history formulated by various policies that determined its creation. According to Soawinski (1997), it was important the establishment of a network of protected areas, stressed from the beginning of the twentieth century, in order to create parks and reserves by the public authorities at various levels, reflecting efforts made to protect ecosystems and biomes.

The road traveled by such policies was drafted by the amendments of laws and decrees aimed at protecting the environment, present on brasilian Presidency of Republic's home page in 2007 and revised in 2016.

- Law number 4771 (September $15^{\text {th }}$ , 1965) - Amendment: To protect natural, exceptional and scientific attributes.

- Law number 5197 (from January $3^{\text {rd }}$, 1967) - Amendment: Prohibits hunting, use, introduction of fauna and flora species, except for scientific 
voltados à proteção do meio ambiente, presentes na home page da Presidência da República em 2007 e revisadas em 2016.

- Lei no 4.771 (de 15 de setembro de 1965) - Ementa: Para resguardar atributos naturais, excepcionais e fins científicos.

- Lei no 5.197 (de 03 de janeiro de 1967) - Ementa: Proíbe a caça, utilização, introdução de espécimes da fauna e da flora, com exceção para atividades de cunho científico.

- Decreto no 84.017 (de setembro de 1979) - Ementa: Regulamenta e estabelece normas que definem e caracterizam os Parques Nacionais.

- Lei no 6.092 (de 27 de abril de 1981) - Ementa: Disposição sobre a criação das Estações Ecológicas e Áreas de Proteção Ambiental (APAs).

- Lei no 6.938 (complementar à Lei no 6.092, datada de 31 de agosto de 1981) - Ementa: Dispõe sobre a Política Nacional do Meio Ambiente, seus fins e mecanismos de formulação e aplicação.

- Decreto no 88.351 (de $1^{\circ}$ de junho de 1983) - Ementa: Execução da Política Nacional do Meio Ambiente.

- Decreto no 89.336 (de 31 de janeiro de 1984) - Ementa: Dispõe sobre as Reservas Ecológicas e Áreas de Relevante Interesse Ecológico.

- Lei no 7.804 (de 18 de julho de 1989) - Ementa: Altera a Lei no 6.938 que dispõe sobre a Política Nacional do Meio Ambiente, seus fins e mecanismos de formulação e aplicação.

- Decreto no 98.897 (de 31 de janeiro de 1990) - Ementa: Regulamenta as Reservas Extrativistas.

- Decreto no 1.298 (de 27 de outubro de 1994) - Ementa: Aprovação e regulamentação das Florestas Nacionais.

Após transcorrer esse caminho, que demandou bastante tempo, ainda mais quando o mesmo é comparado ao cenário estrangeiro, foi constituído o termo Unidade de Conservação (UC) na lei No 9.985/2000, art. $2^{\circ}, \mathrm{I}$, para designar como:

Espaço territorial e seus recursos ambientais, incluindo as águas nature activities.

- Decree number 84017 (September 1979) - Amendment: Regulates and establishes standards that define and characterize the National Parks.

- Law number 6092 (April 27 $7^{\text {th }}$, 1981) - Amendment: Provision on the creation of Ecological Stations and Environmental Protection Areas (APAs).

- Law number . 6938 (complementary to Law number 6.092, dated August 31st, 1981) - Amendment: Provides for the National Environmental Policy, its purposes and mechanisms for formulation and application.

- Decree number 88351 (June $1^{\text {st }}$, 1983) - Amendment: Implementation of the National Environmental Policy.

- Decree number . 89336 (January $31^{\text {st }}$ , 1984) - Amendment: Regulates the Ecological Reserves and Relevant Ecological Areas of Interest.

- $\quad$ Law number 7804 (July $18^{\text {th }}, 1989$ ) - Amendment: Amends Law number 6938 which provides for the National Environmental Policy, its purposes and mechanisms for formulation and application.

- Decree number 98897 (January 31 $1^{\text {st }}$ , 1990) - Amendment: Regulates the Extractive Reserves.

- Decree number 1298 (October 27 $7^{\text {th }}$, 1994) -Amendment: Approval and regulation of National Forests.

After elapse this path, which required a long time, even when it is compared to the foreign scenario, the term Conservation Unit was established (CU) in Law number 9.985/2000, art. 2, I, to designate as:

Territorial space and its environmental resources, including jurisdictional waters, with relevant natural characteristics, legally instituted by the Government, with conservation objectives and defined limits under special administration regime, which is subject to appropriate guarantees of protection (República Federativa do Brasil, 2000).

However, the SNUC has not been declared to the restricted purpose of defining what would be a $\mathrm{CU}$, but the establishment of criterias and rules for their creation, implementation and management, considering the forms of 
jurisdicionais, com características naturais relevantes, legalmente instituído pelo Poder Público, com objetivos de conservação e limites definidos, sob regime especial de administração, ao qual se aplicam garantias adequadas de proteção (República Federativa do Brasil, 2000).

Entretanto, o SNUC não foi promulgado com a finalidade restrita de definir o que seria uma UC, mas sim o estabelecimento de critérios e normas para sua criação, implantação e gestão, considerando as formas de uso desse espaço e o envolvimento da comunidade de entorno no processo. O SNUC, atendendo a finalidade com que foi promulgado, tem como objetivos:

- Contribuir para a manutenção da diversidade biológica e dos recursos genéticos no território nacional e nas águas jurisdicionais;

- Proteger as espécies ameaçadas de extinção no âmbito regional e nacional;

- Contribuir para a preservação e a restauração da diversidade de ecossistemas naturais;

- Promover o desenvolvimento sustentável a partir dos recursos naturais;

- Promover a utilização dos princípios e práticas de conservação da natureza no processo de desenvolvimento;

- Proteger paisagens naturais e pouco alteradas de notável beleza cênica;

- Proteger as características relevantes de natureza geológica, geomorfológica, espeleológica, arqueológica, paleontológica e cultural;

- Proteger e recuperar recursos hídricos e edáficos;

- Recuperar ou restaurar ecossistemas degradados;

- Proporcionar meios e incentivos para atividades de pesquisa científica, estudos e monitoramento ambiental;

- Valorizar econômica e socialmente a diversidade biológica;

- Favorecer condições e promover a educação e interpretação ambiental, a recreação em contato com a natureza e o turismo ecológico; use of that space and the involvement of the community in process. The SNUC, serving the purpose for which it was enacted, aims to:

- Contribute with the maintenance of biological diversity and genetic resources in the national territory and jurisdictional waters;

- Protect endangered species at the regional and national levels;

- Contribute with the preservation and restoration of natural ecosystems diversity;

- Promote sustainable development from natural resources;

- Promote the use of the principles and practices of nature conservation in the development process;

- Protect natural landscapes and little altered of remarkable scenic beauty;

- Protect the relevant geological, geomorphological, speleological, archaeological, paleontological and cultural characteristics;

- Protect and restore water and soil resources;

- Retrieve or restore degraded ecosystems;

- Provide resources and incentives for scientific research, studies and environmental monitoring;

- Valuing economically and socially biological diversity;

- Encourage conditions, promote environmental education and interpretation, recreation in contact with nature and eco-tourism;

- Protect the natural resources necessary for the subsistence of traditional communities, respecting and valuing their knowledge and culture by promoting them socialy and economicaly.

CUs, according to their respective laws are divided into two groups: strictly protected areas and sustainable use. In the first group are listed as CUs: ecological stations, biological reserves, national parks, natural monuments and wildlife refuges, all aimed at permanent protection. In the second group, it allows the use of private property previously located in its corresponding area, encompassing the areas of environmental protection, ecological 
- Proteger os recursos naturais necessários à subsistência de populações tradicionais, respeitando e valorizando seu conhecimento e sua cultura e promovendo-as social e economicamente.

As UCs, conforme suas respectivas Leis encontram-se divididas em dois grupos, unidades de proteção integral e de uso sustentável. No primeiro grupo, estão relacionadas como UCs: estações ecológicas, reservas biológicas, parques nacionais, monumentos naturais e refúgios de vida silvestre, todos destinados à proteção em caráter permanente. No segundo grupo, permite a utilização de propriedades privadas previamente localizadas em sua área correspondente, abarcam áreas de proteção ambiental, de relevante interesse ecológico, florestas nacionais, reservas extrativistas, de fauna, de desenvolvimento sustentável e reserva particular do patrimônio natural. Como o foco deste trabalho está centrado nos parques nacionais, serão considerados os aspectos pertinentes ao primeiro grupo.

A partir do momento em que foram anunciados o desenvolvimento e a implantação das UCs, diversos autores que discorriam sobre os temas voltados à preservação e conservação dos elementos naturais, passaram a discutir a eficácia do SNUC e o papel que o poder público e a comunidade deveriam desempenhar frente às mudanças exigidas quando se constituía uma UC. Dentre as maiores críticas relacionadas, estão as questões fundiárias quando são necessárias desapropriações de terra e remanejamento de propriedades.

Todos esses aspectos ainda são bastante delicados quando analisadas as realidades de muitos parques nacionais e estaduais que ainda se encontram em conflito com a população de entorno, que já usufruía de suas áreas antes da imposição de restrições, por isso "[...] na implementação das unidades de conservação é indispensável que seja realizado previamente à sua criação estudo sobre os aspectos fundiários, ou seja, qual o regime jurídico da propriedade dentro dos limites pretendidos" (Azevedo, p. 29, 2002).

\section{O USO PÚBLICO DAS UCS - OS PARQUES NACIONAIS}

Quando se fala em ecoturismo e sustentabilidade, relacionados às UCs interest, national forests, extractive reserves, wildlife, sustainable development and private reserve of natural heritage. As the focus of this paper is centered on national parks, relevant aspects of the first group will be considered.

From the moment the development and implementation of the CUs were announced, several authors who debated on the issues facing the preservation and conservation of the natural elements, came to discuss the effectiveness of SNUC and the role that the government and the community should carry forward, front the required changes of a $\mathrm{CU}$. Among the main criticisms related are land issues, when land expropriations and relocation of properties are necessary.

All these aspects are still quite delicate when analyzing the realities of many national and state parks that are still in conflict with the surrounding population. The community has used their areas before the imposition of restrictions, so "[...] in implementation of protected areas it is essential that it is carried prior to its creation a study on land issues, i.e. what is the legal regime of the property within the desired limits" (Azevedo, p. 29, 2002).

\section{THE PUBLIC USE OF CUS - NATIONAL PARKS}

When it comes to ecotourism and sustainability, related to the Brazilian CUs, especially national parks, the situation is a bit more complicated than those presented by the theories that guide the planning of the activities offered at these sites.

According to Kinker (2002) in countries such as Ecuador and Costa Rica, when it comes to ecotourism, one automatically assumes that there are protected and well-established areas. In Brazil, however, there is still no such association, because its protected areas lack trained human resources to manage or adequate infrastructure or a management plan, preventing even the development of public use properly.

The negative aspects pointed out by the authors, considering the environment that these CUs are made up, result in negative impacts, direct and indirect. That is, poorly planned actions, visitors becoming part of these actions, making it a paradox when compared with the importance of visitors for the self sustaining of the unit.

Therefore, tourism should be developed in the national parks as a carfully planned 
brasileiras, sobretudo os parques nacionais, a situação é um pouco mais complicada do que aquelas apresentadas pelas teorias que norteiam 0 planejamento das atividades oferecidas nesses locais.

Segundo Kinker (2002), em países como Equador e Costa Rica, quando se fala em ecoturismo, supõem-se áreas protegidas e bem estabelecidas. No Brasil, entretanto, ainda não há essa relação, pois suas áreas protegidas não possuem recursos humanos capacitados para o gerenciamento, nem infraestrutura adequada ou um plano de manejo, impossibilitando até mesmo o desenvolvimento do uso público de maneira adequada.

Os aspectos negativos apontados pelos autores, considerando o ambiente de que essas UCs se compõem, terminam por resultar em impactos negativos, diretos e indiretos, ou seja, ações mal pensadas, visitante que passa a fazer parte dessas ações, tornando-se um paradoxo quando pensado na importância da visitação para o auto sustento da unidade.

Portanto, o turismo deve ser desenvolvido nos parques nacionais tendo como veículo de execução um planejamento bastante cuidadoso, que possa assumir características peculiares, sendo compatível com o manejo da área, o zelo pela conservação, e a geração de renda, ferramenta para o desenvolvido da região onde se localiza e da comunidade do entorno (Kinker, 2002).

A Lei No 9.985 entende como proteção integral a manutenção dos ecossistemas livres de alterações que possam vir a serem causadas pelo homem, admitindo-se apenas o uso indireto. Assim nas unidades que possuem esse caráter, não podem ser consumidos, coletados ou qualquer outra atitude que venha acarretar danos ou destruição dos recursos naturais (República Federativa do Brasil, 2000).

Direcionando esse trabalho especificamente para a questão dos parques nacionais, segundo a mesma lei, esta unidade pertencente ao grupo das UCs que visam a preservação de ecossistemas naturais de grande relevância, permitindo a realização de pesquisas científicas e atividades de educação ambiental, recreação, contato com a natureza e turismo.

Sendo abertos à visitação, essas unidades configuram o uso público, representado, sobretudo pela atividade turística que pode vir implementing vehicle that can take on particular features, and is compatible with the management of the area, the care for conservation and the generating of income , tool for developement of the region where it is located and the surrounding community (Kinker, 2002).

Law number 9.985 understands as full protection the maintenance of the ecosystems free from any alterations that may be caused by man, admitting only the indirect use. So the units that have this character, can not be consumed, collected or any other action that may cause damage or destruction of natural resources (República Federativa do Brasil, 2000).

Directing this paper specifically to the issue of national parks, according to the same law, this unit belonging to the group of CUs for the preservation of natural ecosystems of great importance, allows the conduction of scientific research and environmental education, recreation, and contact with nature and tourism.

Being open to visitors, these units constitute public use, represented mainly by the tourist activity that may prove to have various benefits, exemplified by Barros II (1997), generating income and contributing to conservation programs, job creation, development of economic areas and surrounding communities, especially the growth of environmental awareness.

The author continues with his reflections:

The development of a symbiotic
connection between tourism and
conservation areas will certainly be
very beneficial and on many occasions
it realizes that tourists enjoy the
opportunity to play an active and
interactive role in the preservation
process during his visit, including
encouraging him to return more often
and to induce others to do the same.
Then yes we will have the realization
of philosophical concepts and technical
implementation of a Conservation Unit
(Barros II, p. 303, 1997).

However, the picture found in the protected areas is not as wonderful as many may imagine. The visit of these spaces demand limits and restrictions, because, as all activity, it may well have negative and irreversible changes in these locations. Even the term "tourist" is not used in the media, because every person is considered a visitor, regardless of their origin or intended goals for the visit. 
a trazer diversos benefícios, exemplificados por Barros II (1997), a geração de renda e contribuição para programas de conservação, geração de empregos, desenvolvimento econômico das áreas e comunidades vizinhas, principalmente o crescimento de uma consciência ambiental.

O referido autor continua suas reflexões:

O desenvolvimento de um relacionamento simbiótico entre o turismo e as unidades de conservação certamente será muito benéfico e em muitas ocasiões se perceberá que o turista apreciará a oportunidade de desempenhar um papel ativo e interativo no processo de conservação por ocasião da sua visita, inclusive incentivando-o retornar mais vezes e induzir outras pessoas a fazerem o mesmo. Aí sim teremos a efetivação dos conceitos filosófico e técnicos da implantação de uma Unidade de Conservação (Barros II, p. 303, 1997).

Contudo, o quadro encontrado dentro das UCs não é tão maravilhoso como muitos pensam. A visitação desses espaços demanda limites e restrições, pois, como toda atividade, ela pode vir a acarretar transformações negativas e irreparáveis nesses locais. Até mesmo a denominação "turista" não é utilizada nesses meios, pois, todos são considerados visitantes, independentemente de sua procedência ou objetivos almejados pela visita.

Não são todos os lugares inseridos nos parques (como UCs), que podem ser visitados ou apresentarem estrutura de apoio a visita. Para a estruturação de um determinado parque para o desenvolvimento de atividades, é fundamental a realização do zoneamento de suas terras como parte da elaboração do plano de manejo. Conforme o SNUC, o zoneamento consiste na definição de setores com o objeto de manejo e implantação de normas específicas, proporcionando meios e condições para que os objetivos da unidade sejam alcançados de forma eficaz. O manejo são os procedimentos que asseguram a conservação da biodiversidade e dos ecossistemas.

Kinker (2002) aborda a problemática das questões referentes ao manejo e ao zoneamento ao expor os obstáculos enfrentados no seu decorrer, que incluem ameaças de preservação, conflitos socioculturais de uso dos recursos, falta de verbas e manutenção. Por isso, a autora sugere o ecoturismo como segmento da atividade
Not everywhere inserted in parks (such as CUs), can be visited or show supporting business structure. For the structuring of a particular park for development activities, it is essential to carry out the zoning of their land as part of the preparation of the management plan. As SNUC, zoning is the definition of sectors with the objective of management and implementation of specific regulations, providing means and conditions so that the unit's purposes are achieved effectively. The management are the procedures to ensure the conservation of biodiversity and ecosystems.

Kinker (2002) addresses the issue of questions regarding the management and zoning to expose the obstacles in its course, including threats for preservation, sociocultural conflicts of the use of resources, lack of funding and maintenance. Therefore, the author suggests ecotourism as an appropriate segment of the tourism industry to develop in natural areas, guided by the principles of conservation and the development of incentive policies, allowing the application of resources in visitation. However, in order for this to be possible, a good management plan and calculating the carrying capacity that the local supports is essential. Thus, following this study, the elements relating to the management plan applied in CUs, and the implications that the planning process demands, will be addressed.

\section{SOME CONSIDERATIONS ON THE MANAGEMENT PLAN IN CUS}

The Law number 9985, art. 2, XVII, considers a management plan a technical document, based on the general goals of CU establishing its zoning and rules to be managed in the use of the area and conservation of natural resources, including the implementation of the physical structures necessary for the management of the unit (República Federativa do Brasil, 2000).

One of the biggest challenges in this planning, described by Takahashi (p. 53, 2002) is "[...] to increase the number of employees and give them training conditions, so that the political, social and economic reality in which the units fall is understood using suitable handling techniques".

According to the Methodological Script Planning applied to national parks, biological reserves and ecological stations, developed by Ibama (p. 16, 2002a), the management plan's objectives are centered on: 
turística apropriado para se desenvolver nas áreas naturais, guiado pelos princípios de conservação e pelo desenvolvimento de políticas de incentivo, permitindo a aplicação dos recursos na visitação. Contudo, para que isso seja possível, um bom plano de manejo e do cálculo da capacidade de carga que o local suporta são essenciais.

Assim, na sequência deste trabalho, serão abordados os elementos referentes ao plano de manejo aplicado em UCs, e das implicações que o processo de planejamento deste possui.

\section{ALGUMAS CONSIDERAÇÕES SOBRE O PLANO DE MANEJO EM UCS}

A Lei No 9.985, art. 20, XVII, considera como plano de manejo um documento técnico, baseado nos objetivos gerais da UC, que estabelece o seu zoneamento e normas a serem presididas no uso da área e conservação dos recursos naturais, incluindo a implantação das estruturas físicas necessárias à gestão da unidade (República Federativa do Brasil, 2000).

Um dos maiores desafios nesse planejamento, descrito por Takahashi ( $p$. $53,2002)$ é "[...] como aumentar o número de funcionários e dar-lhes condições de capacitação, de modo que a realidade política, social e econômica, onde as unidades se inserem seja compreendida com o uso de técnicas de manejo adequadas".

De acordo com o Roteiro Metodológico de Planejamento, aplicado a parques nacionais, reservas biológicas e estações ecológicas, desenvolvido pelo Ibama (p. 16, 2002a), os objetivos do plano de manejo estão centrados em:

- Levar a UC a cumprir com os objetivos estabelecidos na sua criação;

- Definir objetivos específicos de manejo, orientando a gestão da UC;

- Dotar a UC de diretrizes para seu desenvolvimento;

- Definir ações específicas para o manejo da UC;

- Promover o manejo da unidade, orientado pelo conhecimento disponível e/ou gerado;

- Estabelecer a diferenciação e intensidade de uso mediante zoneamento, visando a proteção de seus recursos naturais e culturais;
- Take the CU to fulfill the objectives set out in its creation;

- Set specific objectives of management, guiding the management of the $\mathrm{CU}$;

- Provide the CU with guidelines for development;

- Define specific actions for the management of the $\mathrm{CU}$;

- Promote the management of the unit, guided by the knowledge available and/or generated;

- Establish differentiation and intensity of use through zoning, aimed at protecting their natural and cultural resources;

- Highlight the representativeness of the $\mathrm{CU}$ in the SNUC in front of the appreciation of taxes of its resources, such as biomass, conventions and international certifications;

- Establish, as appropriate, standards and specific actions aiming at harmonizing the presence of resident populations with the unit's goals, until it is possible your indemnity or compensation and promote your relocation;

- Establish specific rules regulating the occupation and use of the buffer zone of the resource (ZA) and ecological corridors (EC) aimed at the protection of the $\mathrm{CU}$;

- Promote socio-economic integration of the surrounding communities with the $\mathrm{CU}$;

- Guide the implementation of financial resources for the $\mathrm{CU}$.

According to this methodology, a management plan has three distinctive approaches: the frame of the unit to the reality where it belongs, the diagnosis of their current situation and the development of a plan that covers not only the CU itself, but the whole region in which it is inserted. It is an ongoing process whose implementation lasts up to five years, requiring successive revisions.

The zoning system (2002) determines the subdivision of the site into areas for the management plan configuration, these for the same methodological outline in the related form below:

- Intangibles: preservation of full nature, not allowing human intervention; 
- Destacar a representatividade da UC no SNUC frente aos tributos de valorização dos seus recursos, como biomas, convenções e certificações internacionais;

- Estabelecer, quando couber, normas e ações específicas visando compatibilizar a presença das populações residentes com os objetivos da unidade, até que seja possível sua indenização ou compensação e promover sua realocação;

- Estabelecer normas específicas regulamentando a ocupação e o uso dos recursos da zona de amortecimento (ZA) e dos corredores ecológicos (CE), visando a proteção da UC;

- $\quad$ Promover a integração socioeconômica das comunidades do entorno com a UC;

- Orientar a aplicação dos recursos financeiros destinados à UC.

Segundo a referida metodologia, um plano de manejo apresenta três abordagens distintas: o enquadramento da unidade à realidade em que é pertencente, o diagnóstico de sua situação atual e a elaboração de um planejamento que englobe, não apenas a UC em si, mas toda a região em que se encontra inserida. Ela é um processo contínuo cuja implantação se prolonga por até cinco anos, sendo necessárias sucessivas revisões.

O sistema de zoneamento a (2002) determina a subdivisão do local em áreas para a configuração do plano de manejo, estas pelo mesmo roteiro metodológico da forma relacionada abaixo:

- Intangível: preservação da natureza integralmente, não se permitindo intervenções humanas;

- Primitiva: permite a mínima intervenção humana e a realização de atividades de pesquisa, educação ambiental e recreação;

- De Uso Extensivo: pode apresentar uma quantidade maior de intervenções, se configurando também como área transitória entre as áreas primitiva e de uso intensivo;

- De Uso Intensivo: locais modificados pela ação humana onde podese construir centros de visitantes, museus, e estruturas para o oferecimento de outros serviços;
- Primitive: allows minimal human intervention and the realization of research activities, environmental education and recreation;

- Extensive Use: can require a greater number of interventions, configured also as a transitional area between the primitive and intensive areas;

- Intensive use: places modified by human action, where visitor centers, museums and facilities can be built offering other services;

- Historical-Cultural: destined for the protection of historical sites presented for the subsequent interpretation of visitors, research, education and scientific use;

- Recovery: also formed by areas altered by man, however, areas that are in recovery for subsequent classification as intangible area;

- Special Use: where are located the administration centers, maintenance and service for the CUs;

- Conflicting Use: places that were already established before the implementation of the CU, holders of goals that conflict with the unit;

- Temporary Occupation: areas within the CUs that concentrate resident inhabitants;

- Indigenous Overlap: areas occupied by indigenous groups;

- Experimental interference: specific to Ecological Stations consists of areas for the development of research;

- Attenuation: around the CU, where the activities are subject to restrictions.

The site Environment Brazil (2007), mentions about the planning of the CUs for the development of a management plan, says it is important to understand when the planned objectives are reached and should not be confused with its own plan objectives, as this ends up making the management tool ineffective.

Despite the demands made by Ibama and the Ministry of Environment (MMA), some CUs still do not have an effective management plan, relying only on empirical processes and the adoption of previous experiences which have had good results, this practice is named by the site Environment Brazil (2007) as moderate management. 
- Histórico-Cultural: destinados à proteção dos sítios históricos presentes para a posterior interpretação dos visitantes, pesquisa, educação e uso científico;

- De Recuperação: igualmente formada por áreas alteradas pelo homem mas que encontram-se em processo de recuperação para a posterior classificação em área intangível;

- De Uso Especial: lugar onde se localizam os centros de administração, manutenção e serviço das UCs;

- De Uso Conflitante: lugares que já estavam consolidados antes da implantação da UC possuidoras de objetivos que entram em conflito com os da unidade;

- De Ocupação Temporária: áreas dentro das UCs que concentram habitantes residentes;

- De Superposição Indígena: áreas ocupadas por etnias indígenas;

- De Interferência Experimental: específica para Estações Ecológicas é constituída por áreas para o desenvolvimento de pesquisas;

- De Amortecimento: entorno da UC, onde as atividades estão sujeitas a restrições.

O site Ambiente Brasil (2007), ao dissertar sobre o planejamento das UCs para a formação do plano de manejo, afirma que é fundamental se entender o sentido de se chegar aos objetivos traçados, não devendo confundi-lo com os próprios objetivos do plano, pois isso acaba tornando o instrumento de manejo utilizado ineficaz.

Apesar das exigências feitas pelo Ibama e pelo Ministério do Meio Ambiente (MMA), algumas UCs ainda não possuem um plano de manejo efetivo, apoiando-se em processos empíricos e adoção de experiências anteriores que surtiram resultados, forma esta denominada pelo site Ambiente Brasil (2007) manejo moderado.

Analisando o posicionamento dos parques, de acordo com os dados presentes na home page do Ibama (2002a) em relação aos parques nacionais, dos sessenta e dois parques que constam na lista consultada em 2007, apenas nove não possuem plano de manejo, estes fundados oficialmente a partir do ano de 2004.
Analyzing the positioning of parks, according to the data existent on Ibama's home page (2002a) in relation to national parks, from the sixty-two parks listed in the list referred in 2007, only nine have no management plan, these have been officially created in 2004.

The composition of a management plan is not only a technique involving extensive surveys of the site characteristics and integration in regional, state and national scenarios. It also involves the surrounding community that participates in the process of decision making. Therefore, as Padua (2002) says, CUs must help local economic development, it is essential to include in their management plans, business plans, prepared by the social actors, indicating opportunities to improve their quality without compromising biodiversity conservation, being the tourism one of those possibilities.

Among the elements considered by the management plan, are the methods chosen for the assessment of site carrying capacity, i.e. what is the limit of visitors the place can receive daily.

For the understanding of the chosen object of study and the fulfillment of the objectives that this paper has, some approaches will be related on the subject.

\section{THE CARRYING CAPACITY IN CUS}

According to Pires (2005), the term capacity was adapted to carrying capacity which, under the tourism perspective, is the ability that a given space has to withstand the flow of visitors while preserving its integrity and original features, that is, considering the tolerance level that the zone is going to have towards the impacts caused by man.

According to the same author, the concept of carrying capacity in tourism was created in the 1970s, when it began to be applied in natural environments, causing the essence of his concept to passed through a constant maturity to the present day.

The load capacity has several types of approaches, numerical standards aimed at its implementation and integrated management systems of protected areas. Regarding the typologies, Pires (2005) gave an overview of concepts and terms used by several authors to group the ways in which the capacity is presented, resulting in the following: 
A composição de um plano de manejo, não é apenas uma técnica envolvendo extensos levantamentos das características do local e inserção nos cenários regional, estadual e nacional, ela envolve também a comunidade de entorno que participa das tomadas de decisões. Por isso, como Pádua (2002) ressalva, as UCs devem ajudar no desenvolvimento econômico local, sendo indispensável a inclusão nos seus planos de manejo, de planos de negócios, elaborados pelos atores sociais, que indiquem possibilidades de melhorar a sua qualidade sem comprometer a preservação da biodiversidade, sendo o turismo uma dessas possibilidades.

Dentre os elementos considerados pelo plano de manejo, estão os métodos escolhidos para a avaliação da capacidade de carga do local, ou seja, qual o limite de visitantes que ele pode receber diariamente.

Para a compreensão do objeto de estudo escolhido e o atendimento dos objetivos a que este trabalho se dispõe, serão relacionadas algumas abordagens sobre $o$ assunto.

\section{A CAPACIDADE DE CARGA NAS UCS}

Segundo Pires (2005), o termo capacidade foi adaptado de carrying capacity que, sob a perspectiva do turismo, consiste na capacidade que um determinado espaço possui para suportar o fluxo de visitantes preservando sua integridade e características originais, ou seja, considerando-se o nível de tolerância que o local terá perante os impactos causados pelo homem.

Conforme o mesmo autor, a concepção da capacidade de carga no turismo foi idealizada na década de 1970, quando começou a ser aplicada em ambientes naturais, fazendo com que a essência de seu conceito passasse por um amadurecimento constante até os dias de hoje.

A capacidade de carga possui vários tipos de enfoques, padrões numéricos direcionados à sua implantação e sistemas integrados de gestão das áreas protegidas. Com relação às tipologias, Pires (2005) fez uma síntese de conceitos e termos utilizados por vários autores para agrupar as formas em que a capacidade se apresenta, resultando nos seguintes elementos:

- Capacidade de carga ecológica - identifica as transformações produzidas no ecossistema pelo uso
- Ecological carrying capacity identifies the changes produced in the ecosystem by tourist use, this translated in numbers, where the maximum number of users, days of operation, recreational use and tourism activity are set ;

- Perceptive / psychological / ecological capacity - relates the degree of saturation of a resource with the expectation and quality of experience, where the number of simultaneous visitors can saturate the location, damaging the living and the recreational use;

- Landscape capacity - capacity that the landscape has to visually absorb the amount of visitors;

- $\quad$ Equipment capacity - physical aspects of the site and the safety conditions presented to the tourist, avoiding the excess of visitors and facilities that could affect the landscape;

- Physical capacity - number of installations for the use of visitors who may be physically absorbed in a given space, since then, developing the recreational carrying capacity;

- Economic capacity - a situation in which the available resources are used for economic activities and recreation;

- Environmental capacity - maximum level of tourists, before any decline in services could be noticed by the tourist.

Numerical standards adopted to establish the amount of allowed visitors, in lieu of the physical and structural characteristics of space, Pires (2005), quotes those most commonly used in the definition of the ideal density patterns: Cifuentes Method (includes the physical load capacity, real and effective, i.e., it will not cause damage to the long term); Proposal for Boullon (developed considering the Latin American reality, which is assigned a value to space, total daily visits multiplied by turnover coefficient); Salinas Formula (also made by mathematical means, but this encompassing characteristics of the place); Density and Tourist use patterns (using indicators based on user density, territorial unit, recreational type of natural area activities or possible zoning in the case of protected areas, for example).

For a $\mathrm{CU}$, it is not enough just to control the carrying capacity through numbers and 
turístico, esta traduzida por meio de números, onde se fixa o número máximo de usuários, de dias de funcionamento, do uso recreativo e da atividade turística;

- Capacidade perceptiva/ psicológica/ ecológica - relaciona o grau de saturação de um recurso com a expectativa e qualidade da experiência, onde 0 número de visitantes simultâneos pode saturar o local, prejudicando a vivência e o uso recreativo;

- Capacidade paisagística - capacidade que a paisagem tem de absorver visualmente a quantidade de visitantes;

- Capacidade material - aspectos físicos do local e as condições de segurança apresentadas ao turista, evitando o excesso de visitantes e instalações que venham a afetar a paisagem;

- Capacidade física - número de instalações para o uso dos visitantes que podem ser absorvidas fisicamente em espaço determinado para, a partir de então, se desenvolver a capacidade de carga recreativa;

- Capacidade econômica - situação em que os recursos disponíveis são empregados para atividades econômicas e de recreação;

- Capacidade ambiental - nível máximo de uso turístico antes de ser percebido declínio por parte do turista.

Dos padrões numéricos utilizados para a estipulação da quantidade de visitantes permitida, em detrimento às características físicas e estruturais do espaço, Pires (2005), cita aqueles mais comumente empregados na definição dos padrões de densidade ideais: Método Cifuentes (abarca as capacidades carga física, real e a efetiva, ou seja, a que não virá a causar danos ao meio em longo prazo); Proposta de Boullón (desenvolvida considerando a realidade latino-americana, onde atribui-se um valor ao espaço, ao total de visitas diárias, multiplicados por coeficiente de rotatividade); Fórmula de Salinas (feita também por meio matemático, mas este englobando características particulares do local); Densidade e Padrões de uso Turístico (se utiliza de indicadores baseados na densidade de usuários, unidade territorial, atividades recreativas tipo de área natural ou visitors restrictions. It requires a continuous process of site maintenance in order to guarantee the integrity of the biodiversity, configured as Pires (2005) describes in the management models aimed at public use of these protected areas, citing by Eagles, Mccool $\&$ Haynes (2002), the most used worldwide:

- Recreational Opportunity Spectrum (ROS): Model zoning created for the American territory and can be applied in protected areas or in landscape planning according to the recreational activities developed and tourism demand. It comprises the inventory of physical, social and administrative conditions that influence the visits, to monitoring, with the definition of six classes of recreational opportunities based on indicators that determine visits.

- $\quad$ Limits of Acceptable Change (LAC): also developed in the United States, it is directed to the impacts of recreation, establishing the extent to which changes caused by tourism are acceptable. It involves nine stages (of these, the second is the application of ROS) that result in a strategic and tactical plan for the area in which the method was based with the purpose to encourage management decision making.

- Visitor Impact Management (VIM): another American model, consists of a methodology of identification and monitoring of impacts similar to LAC, by relying on indicators to define the impacts classified as unacceptable, but detecting their causes and formulating strategies to solve the problems identified. The method also provides levels of impact and management criteria with the conditions of visitation.

- Visitor Activity Manegement Process (VAMP): presented by Canada, this model provides the input for the identification and management opportunities for visitors of CUs. It is an extension of the VIM, working with focus on management of users, through programs of orientation and guidance to the services offered by incorporating the ROS and extending to the others described methodologies.

- Tourism Optimization Model (TOM): developed in Australia, has as its starting point the LAC in order to control the tourism based on sustainable yields (leaving in the 
ainda possível zoneamento, no caso das UCs, por exemplo).

Para uma UC, não basta apenas o controle da capacidade de carga por meio de números e de restrições de visita. Ele necessita de um processo continuo de manutenção do local como forma de garantir a integridade da biodiversidade, configurado, como Pires (2005) descreve, nos modelos de gestão voltadas ao uso público dessas áreas protegidas, citando por meio de Eagles, Mccool \& Haynes (2002), os mais utilizados em âmbito mundial:

- Espectro de Oportunidades Recreativas (Recreation Oportunity Spectrum - ROS): modelo de zoneamento criado para o território americano, podendo ser aplicado em áreas protegidas ou no planejamento da paisagem conforme as atividades de recreação desenvolvidas e a demanda turística. Compreende o inventário das condições físicas, sociais e administrativas que influem na visita, até o monitoramento, com a definição de seis classes de oportunidades recreativas com base em indicadores que determinam as visitas.

- Limites Aceitáveis de Alteração (Limits of Acceptable Change LAC): também desenvolvido nos Estados Unidos, se direciona aos impactos causados pela recreação, estabelecendo até que ponto as alterações causadas pela atividade turística são aceitáveis. Ele envolve nove etapas (destas, a segunda é a aplicação do ROS) que resultam em um plano estratégico e tático para a área em que se fundamentou o método, que fomentará as tomadas de decisões de gestão.

- Gestão do Impacto de Visitantes (Visitor Impact Management - VIM): outro modelo americano consiste em uma metodologia de identificação e monitoramento de impactos semelhante ao LAC, por se basear em indicadores para definir os impactos classificados como inaceitáveis, mas detectando suas causas e formulando estratégias para solucionar os problemas detectados. O método também estabelece níveis de impacto e critérios de manejo conforme as condições da visitação. background the maximum levels of use) identified policies, values of the community, local characteristics and growth trends.

- Visitor Experience and Resource Protection - VERP: model created in the United States, it has desirable perspectives for the features and conditions of use, defining which levels of use are acceptable and in which circumstances. It is similar to VAMP, having as process management emphasis zoning space.

Analyzing these management models, Pires (2005) identified similarities between them, these similarites are perceptible only in the analysis of its definitions, however, they also have limiting, especially in respect of the investments in planning and their effectiveness. When the Brazilian reality is analyzed in this context, the two limiters become even more problematic when faced with the lack of resources that the managers of protected areas constantly face, and who come to harm both the visitor, as the preservation of the ecosystems and biodiversity.

\section{THE CASE OF LAGOA DO PEIXE NATIONAL PARK (RS-BRAZIL)}

Lagoa do Peixe National Park is located in the municipality of Mostardas having as limits: South - municipalities of Tavares and São José do Norte; West - restinga forest; East - Ocean from the southern limit to the Mostardas Lighthouse; and North - condominium Porto dos Casais, as seen in Figure 1. The park was created by Decree number 93546, from November 6, 1986, having as main features the vegetation of restinga and the coastal and marine ecosystems.

The Lagoa do Peixe National Park was created after the suggestion of the Brazilian Institute for Forestry Development - IBDF current Ibama, for the protection of migratory birds, that were located on the location, to feed and rest during their migration processes. The site also functioned as a shelter in the winter for species such as the flamingo and the maçarico-de-papo-vermelho.

As a second creation objective, is the preservation of wetlands as part of the international campaign to preserve these. Years later, in 1991, the park was included in the Hemispheric Network Waders Bird Reserve 
- Processo de Gestão de Visitação (Visitor Activity Manegement Process - VAMP): apresentado pelo Canadá, esse modelo oferece o aporte para a identificação e gestão de oportunidades para os visitantes das UCS. É uma ampliação do VIM, funcionando com foco na gestão dos usuários, por meio de programas de interpretação e orientação aos serviços oferecidos, incorporando o ROS e se estendendo ás outras metodologias descritas.

- Modelo de Otimização do Turismo (Tourism Optimization Model - TOM): desenvolvido na Austrália, tem como ponto de partida o LAC, visando controlar a atividade turística com base em rendimentos sustentáveis (deixando em segundo plano os níveis máximos de uso) identificado políticas, valores da comunidade, características locais e tendências de crescimento.

- Proteção aos Recursos e á Experiência dos Visitantes (Visitor Experience and Resource Protection - VERP): novo modelo criado pelos Estados Unidos, trata-se de perspectivas desejáveis para os recursos e condições de utilização, definindo quais níveis de uso são aceitáveis e em que circunstâncias. É similar ao VAMP, tendo como ênfase de gestão do processo o zoneamento do espaço.

Analisando os referidos modelos de gestão, Pires (2005) identificou similaridades entre os mesmos, estas perceptíveis apenas na análise de suas definições, contudo, eles também apresentam limitantes, sobretudo em relação aos investimentos constantes em planejamento e a efetividade dos mesmos. Quando analisada a realidade brasileira no presente contexto, os dois limitadores se tornam uma problemática ainda maior, quando deparados com a falta de recursos com que os administradores das UCs constantemente se deparam, e o que vêm a prejudicar tanto a visitação, quanto a própria preservação dos ecossistemas e da biodiversidade.

\section{O CASO DO PARQUE NACIONAL DA LAGOA DO PEIXE (RS)}

O Parque Nacional da Lagoa do Peixe está localizado no município de Mostardas, tendo by the International Association of Fish Wildlife Agency, in the category International reserves.

In subsequent years, the park was included in the Atlantic Forest Reserve of Biosphere in the category of Core Zone, qualification awarded by UNESCO; site included in the treaty of the Ramsar Convention; and pilot area of Atlantic Forest Reserve of the Biosphere in Rio Grande do Sul.

Besides the particular characteristics identified on the location, the park does not have a fully regulated area due to land issues. According to the management plan there are two distinct situations: private property and marine land.

When the park was created, the had farms, where many of the owners sold their land or refused to leave the site, because of the dependance on the support brought by the land. Thus, the particular properties started to belong to the $\mathrm{CU}$ and over time, some of these areas were acquired by Ibama, being the owners compensated.

The Marine land, being considered by the Federal Constitution as goods that belong to the Union, had their land reallocated for use of CUs as part of the beach that belongs to the Tavares city lies within the park. Many vacationers had built their homes in these places, demanding basic infrastructure by the government, an argument that clashed with the park objectives.

In this same area there is also a fishing village, in addition to three tourist beaches, all lacking in infrastructure, with no sewage treatment, supply, water and waste disposal (present only in the summer period). This situation is exacerbated by the erosion that the coastal space presents, causing the ruin of several homes and forcing people to leave the place.

Under such adverse conditions, which cause numerous impacts to preserving this ecosystem, the $\mathrm{CU}$ has been treating the elements aimed at their carrying capacity. Next, the method found for managing the National Park of Lagoa do Peixe will be related and analysed.

\section{THE MANAGEMENT PLAN AND THE CARRYING CAPACITY OF LAGOA DO PEIXE NATIONAL PARK}

Considering the stage where a management plan is based, i.e. the service of CU's goals 
como limites: Sul - municípios de Tavares e São José do Norte; Oeste - mata de restinga; Leste - oceano do limite sul até o Farol de Mostardas; e Norte - condomínio Porto dos Casais, pode ser visualizado na figura 1 . 0 parque foi criado pelo Decreto No 93.546 de 6 de novembro de 1986, tendo como principais características a vegetação de restinga e ecossistema costeiro e marinho.

O Parque Nacional da Lagoa do Peixe foi criado por sugestão do Instituto Brasileiro de Desenvolvimento Florestal - IBDF, atual Ibama, para a proteção das aves migratórias que se concentravam no local para se alimentar e repousar durante seus processos de migração. O local também servia de abrigo no inverno para espécies como o flamingo e maçarico-de-papo-vermelho.

Como segundo objetivo de criação, está a preservação de áreas úmidas, como parte da campanha internacional de preservação destas, anos depois, em 1991, o parque foi incluído na Rede Hemisférica de Reserva de Aves Limícolas pela International Association of Fish Wildlife Agency, na categoria Reserva Internacional.

Nos anos subsequentes, o parque foi incluído na Reserva da Biosfera da Mata Atlântica na categoria de Zona de Núcleo, diploma concedido pela Unesco; local incluso pelo tratado da Convenção de Ramsar; e área piloto da Reserva da Biosfera da Mata Atlântica no Rio Grande do Sul.

Apesar das características particulares identificadas no local, o parque ainda não possui sua área totalmente regulamentada devido á questões fundiárias. Conforme o plano de manejo existe duas situações distintas: propriedades particulares e terrenos de marinha.

Quando o parque foi criado, havia no local, propriedades rurais, onde muitos dos proprietários venderam suas terras ou se recusaram a sair do local, por dependerem do sustento trazido pela terra. Deste modo, as propriedades particulares passaram a pertencer à UC, e com o passar do tempo, algumas destas áreas foram adquiridas pelo Ibama, tendo indenizado os proprietários.

Os terrenos da Marinha, por serem considerados pela Constituição Federal como Bens da União, tiveram suas terras remanejadas para uso da UC, pois a parte da praia que pertencente à cidade de Tavares encontra-se dentro do parque. Muitos veranistas haviam construído suas casas nesses locais, passando during the planning, Lagoa do Peixe National Park (Ibama, 2002b) lists the following:

- Preserve the coastal dunes and the estuarine system of Lagoa do Peixe;

- Protect the marine area favoring the maintenance of the genetic bank;

- Provide environmental education integrating the local population in environmental preservation;

- $\quad$ Preserve the environmental conditions for migratory birds;

- Contribute to the preservation of regional biodiversity;

- Protect exceptional features of geological, geomorphological, archaeological, paleontological and cultural nature;

- Protect water resources and the hydrological dynamics of the region;

- $\quad$ Provide the scientific knowledge of the natural and cultural environment of the Restinga;

- Protect rare and/or endangered species, especially migratory birds;

- Contribute to the improvement of the local population's quality of life through an integrated regional planning;

- Promote eco-tourism and leisure in contact with nature.

Guided by these objectives, park planning was initiated based on the methodological scripts and laws that concern the area to be contextualized the corresponding space, divided into five phases of implementation, which include: acceptance of the park by the community, land regulation, involvement of society, political will, continuity, interest of partners, availability of financial resources, human resources and commitment to Ibama's. Focusing specifically on the zoning of land belonging to the park, five zones have been defined: primitive, extensive use, intensive use, special use and recovery, not mentioned the conflicting areas with the park objectives.

Among the activities, develop contemplation, bird watching, hiking and environmental education are intender, among others. Specially with tourists heading to the site. Since the park, according to its management plan, is one of the main tourist attraction in its region, so the study was conducted for the local carrying capacity. 
a exigir infra-estrutura básica por parte do governo, argumento que entrou em choque com os objetivos do parque.

Nessa mesma área também existe uma vila de pescadores, além dos balneários de veranistas (três), todos desprovidos de infraestrutura, não existindo tratamento de esgoto, abastecimento, de água e coleta de lixo (presente somente no período de veraneio). Essa situação é agravada pela erosão que o espaço litorâneo apresenta, ocasionando a ruína de várias casas e forçando as pessoas a abandonarem o lugar.

Sobre tais condições adversas, que causam inúmeros impactos à preservação desse ecossistema, como a UC vem tratando os elementos voltados à sua capacidade de carga. A seguir, será relacionando o método encontrado para a gestão do Parque Nacional da Lagoa do Peixe e as análises tecidas em relação ao mesmo.

\section{O PLANO DE MANEJO E A CAPACIDADE DE CARGA DO PARQUE NACIONAL DA LAGOA DO PEIXE}

Considerando as fases em que um plano de manejo se baseia, ou seja, o atendimento dos objetivos da UC durante o planejamento, - Parque Nacional da Lagoa do Peixe (Ibama, 2002b) elenca os seguintes:

- Preservar as dunas costeiras e o sistema estuarino da Lagoa do Peixe;

- Proteger a área marinha favorecendo a manutenção do banco genético;

- Propiciar a Educação Ambiental integrando a população local na preservação do ambiente;

- Preservar as condições ambientais para as aves migratórias;

- Contribuir para a preservação da biodiversidade regional;

- Proteger características excepcionais de natureza geológica, geomorfológica, arqueológica, paleontológica e cultural;

- Proteger os recursos hídricos e a dinâmica hidrológica da região;

- Propiciar o conhecimento científico do ambiente natural e cultural da restinga;

- Proteger as espécies raras e/ou ameaçadas de extinção, em especial as aves migratórias;
The methods used for the stipulation of load capacity, described in this study, the park opted for LAC, claiming that it is a more acceptable procedure, it is not concerned with the amount of use that an area may have, but how this use is made. Thus, according to the structure presented by the Park (Ibama, 2002b), the unit's carrying capacity was defined in:

- Talha-mar Development Area: 150 people / 4 hours

- Development Area of Colhereiros: 100 people / 4 hours

- Development area of Barra da Lagoa do Peixe: 20 people per tour

- $\quad$ Lighthouse Development area: 50 people / 3 hours

- Development Area of Figueiras: 60 people / 4 hours

- Flamingos trail: 20 people per tour

- Talha-mar track: 20 people per tour

- Trail of dunes: 20 people per tour

- Trail of Figueiras: 20 people at a time

Based on the way that stipulated the carrying capacity, some issues that should be addressed were analyzed, when it comes to a marine area that has become a national park.

In the case of Fernando de Noronha National Park, there are ways to control the entry and exit of those who go to the coastal strip, for example, sea bathing. But how to proceed in the case of this park? When the management plan was read, arguments to answer this question were not found. Other major problems detected are the land resolutions, evidencing the difficulty of reconciling the interests of landowners on site, with the objectives of the Conservation Unit.

The LAC model, widely used in Brazil, according to the analysis made by Pires (2005) from Eagles, Mccool \& Haynes (2002), presents several limiting with respect to the effectiveness of the method, based on experience, which may come to demand in the long term, several conduct corrections .

Takahashi (2004), when speaking of the method, defines principles that were not present in the first version, which are then synthesized as key to the preservation of natural environments. These principles, going to the theoretical source of the methodology, are divided into nine steps: Identification of values; Concerns and limitations; 
- Contribuir para a melhoria da qualidade de vida da população local através de um planejamento regional integrado;

- Favorecer o ecoturismo e o lazer em contato com a natureza.

Norteado por esses objetivos o planejamento do parque foi iniciado tendo como base os roteiros metodológicos e legislações que tangem a área para ser contextualizado o espaço correspondente, dividindo-se em cinco fases de execução, que abrangem: aceitação do parque pela comunidade, regularização fundiária, envolvimento da sociedade, vontade política governamental, continuidade administrativa, interesse dos parceiros, disponibilidade de recursos financeiros, recursos humanos e comprometimento do Ibama com o plano. Focando especificamente no zoneamento das terras pertencentes ao parque, foram delimitadas cinco zonas: primitiva, de uso extensivo, de uso intensivo, de uso especial e de recuperação, não sendo mencionadas as áreas conflitantes com os objetivos do parque.

Entre as atividades, pretende-se desenvolver a contemplação, observação de aves, trilhas, atividades de educação ambiental, entre outras, sobretudo com os turistas que se dirigem ao local, uma vez que, o parque conforme seu plano de manejo, é um dos principais atrativos turísticos de sua região, deste modo foi realizado o estudo da capacidade de carga do local.

Dos métodos mais utilizados para a estipulação da capacidade de carga, descritos nesse trabalho, o parque optou pelo LAC, alegando que o mesmo representa um procedimento mais aceitável, pois não se preocupa com a quantidade de uso que uma área pode ter, mas como este uso é feito. Assim, conforme a estrutura apresentada pelo parque (Ibama, 2002b), a capacidade de carga da unidade foi definida em:

- Área de Desenvolvimento do Talhamar: 150 pessoas/4 horas

- Área de Desenvolvimento dos Colhereiros: 100 pessoas/4 horas

- Área de Desenvolvimento da Barra da Lagoa do Peixe: 20 pessoas por passeio

- Área de Desenvolvimento do Farol: 50 pessoas/3 horas

- Área de Desenvolvimento das
Description of areas; Selection of impact indicators; inventory of existing resources and conditions; Specification of Limits indicators; Identification of conditions for each zone along with management actions for each option; Evaluation and selection of the best options; Implementation and monitoring of conditions.

By analyzing the conditions presented during the management plan for the application and carrying capacity, the park provides changes, if necessary in the long term. Amounts of allowed visitors may be reduced or increased, if damage is not detected in the unit, by means of monitoring studies.

\section{FINAL CONSIDERATIONS}

After concluding this study, it was possible to get an overview of the inserted tourism in protected areas, supported by the SNUC, management plan and fixation methods of carrying capacity that the same support as a way to facilitate the contact of man with nature without damaging it. Lagoa do Peixe National Park, located in the State of Rio Grande do Sul - Brazil, has a well structured management plan and carrying capacity method (LAC) set. However, since its creation in 1986, it suffers from land issues, with many properties inserted in and around the park without basic sanitation infrastructure, water, sewage and waste disposal, that undertake the stipulated park area.

For a better reality display made up by these land issues, it would be interesting to conduct a field survey with the owners and park management members to the frame composition formed by these issues. Unresolved issues could bring irreversible damage to the ecosystem that the park aims to protect and conserve.

While the research was conducted, criticism related both to the effectiveness of the SNUC and to the applicability of the management plans were found within these units. The aspects that are on paper, in many cases by CUs (especially in national parks), serve only to fulfill formalities, and the main function of these, is in the background, which is the conservation and preservation of nature.

An example of this case may be the fact that the wanted management plans for the development of this paper were not received, because, from the contacts made, one was 
Figueiras: 60 pessoas/4 horas

- Trilha dos Flamingos: 20 pessoas por passeio

- Trilha do Talha-mar: 20 pessoas por passeio

- Trilha das Dunas: 20 pessoas por passeio

- Trilha das Figueiras: 20 pessoas por vez

Tendo como base a forma com que se estipulou a capacidade de carga, foram analisadas algumas questões que devem ser abordadas quando se trata de uma área Marinha que vem a se tornar parque nacional.

No caso do Parque Nacional de Fernando de Noronha, existem formas de controlar a entrada e a saída daqueles que se dirigem à faixa litorânea para, por exemplo, o banho de mar. Mas como proceder no caso desse parque? Quando foi lido o plano de manejo, não foram encontrados argumentos para responder a essa questão. Outra grande problemática detectada são as resoluções fundiárias, ficando evidente a dificuldade de conciliar os interesses dos proprietários de terras no local, com os objetivos da Unidade de Conservação.

O modelo LAC, amplamente empregado no Brasil, conforme nas análises feitas por Pires (2005) a partir de Eagles, Mccool \& Haynes (2002), apresenta diversos limitantes com relação à efetividade do método, com base na experiência, o que pode vir a demandar, em longo prazo, várias correções de conduta.

Takahashi (2004), quando fala do método, delimita seus princípios que na primeira versão não eram presentes, sendo estes posteriormente sintetizados como elementos fundamentais à preservação de ambientes naturais. Esses princípios, indo à fonte teórica da metodologia, se dividem em nove etapas: identificação de valores; preocupações e limitações; descrição das zonas; seleção de indicadores de impacto; inventário de recursos e condições existentes; especificação dos limites de indicadores; identificação das condições para cada zona, juntamente com as ações de manejo para cada opção; avaliação e seleção das melhores opções; implementação e monitoramento das condições.

Pela análise das condições apresentadas no decorrer da aplicação do plano de manejo e da capacidade de carga, o parque prevê mudanças, se necessárias, em longo prazo, answered by saying that the park had no management plan, a reality that can not last in Brazil.

On the results and the limiting factors found in this research, using new methods of research about the topic addressed are suggested. Currently the home page of the ICMBio - Chico Mendes Institute for biodiversity conservation - offers several management plans for consultation, thus facilitating the expansion of the research field

While there are no effective tools to ensure its implementation, the most affected character in this process is nature itself. Brazil has parks where these mechanisms work, but there are many others who daily fierce battles where environmentalists and civil society's interests are fought. It is up to the academy to continue calling public attention to these issues.

\section{REFERENCES}

Ambiente Brasil. Plano de manejo de parques nacionais (2007). Retrieved from ww.ambientebrasil.com.br

Azevedo, P. U. E. de. (2002). Implementando as unidades de conservação: particularidades da regularização fundiária. In Milano, M. S. Unidades de Conservação: atualidade e tendências (pp. 17-30) Curitiba: Fundação O Boticário de Proteção à Natureza.

Barros II, S. M. (1997). Turismo e unidades de conservação no Brasil. In Congresso Brasileiro de Unidades de Conservação (pp. 298-319). Curitiba: IAP/UNILIVRE/Rede Nacional Pró-Unidade de Conservação.

Eagles, P. F. J., Mccool, S. F., \& Haynes, C. D. (2002). Sustainable tourism in protected areas: guidelines for planning and management. Best Practice Protected Areas Guidelines Series (8). IUCN: The World Conservation Union.

Instituto Brasileiro do Meio Ambiente e dos Recursos Naturais Renováveis. Ibama. Roteiro metodológico de planejamento: Parque Nacional, Reserva Biológica, Estação Ecológica (2002a). Edições Ibama. Retrieved from http://www.ibama.gov.br/ siucweb/unidades/roteiro_metodologico_ revisado_05_2005.pdf.

Instituto Brasileiro do Meio Ambiente e dos Recursos Naturais Renováveis. Ibama. Unidades de conservação - Parques Nacionais (Parque Nacional da Lagoa do Peixe). Plano de Manejo (2002b). Retrieved from http://www.ibama.gov.br. 
podendo ser reduzida a quantidades de visitantes permitidas ou aumentada, se não forem detectados danos à unidade por meio de estudos de monitoramento.

\section{CONSIDERAÇÕES FINAIS}

Com a finalização desse trabalho, pôde-se obter um panorama do turismo inserido nas UCs, amparadas pelo SNUC, plano de manejo e métodos de fixação da capacidade de carga que as mesmas suportam, como forma de viabilizar o contato do homem com a natureza sem causar danos a esta.

O Parque Nacional da Lagoa do Peixe, localizado no Estado do Rio Grande, possui um plano de manejo bem estruturado e método de capacidade de carga (LAC) definido, todavia, desde sua criação em 1986, ainda sofre com as questões fundiárias, tendo muitas propriedades inseridas dentro e nas proximidades do parque sem infra-estrutura de saneamento básico, água, esgoto e coleta do lixo, que comprometem a área estipulada do parque.

Para uma melhor visualização da realidade composta por essas questões de terras, seria interessante a realização de uma pesquisa de campo com proprietários e membros da administração do parque para a composição do quadro formado por essas questões que, se não forem resolvidas, trarão danos irreversíveis ao ecossistema que o parque visa proteger e conservar.

Durante as pesquisas realizadas, foram encontradas críticas relacionadas, tanto a efetivação do SNUC quanto a aplicabilidade dos planos de manejo dentro dessas unidades. Os aspectos que se encontram no papel, em muitos casos por UCs (em especial parques nacionais), servem apenas para cumprir formalidades, e a principal função destes, fica em segundo plano, que é a conservação e preservação da natureza.

Como exemplo desse caso, pode ser relacionada a não obtenção dos planos de manejo desejados para o desenvolvimento deste trabalho, pois, dos contatos feitos, um foi respondido, dizendo que o parque não possuía plano de manejo, uma realidade que não pode perdurar no Brasil.

Diante dos resultados e dos fatores limitantes encontrados nesta pesquisa, sugerimos que sejam utilizados novos métodos de pesquisa, com relação a temática
Kinker, S. (2002). Ecoturismo e conservação da natureza em parques nacionais. Campinas: Papirus.

Pádua, M. T. J. (2002). Unidades de Conservação: muito mais do que a criação e planos de manejo. In Milano, M. S. Unidades de Conservação: atualidade e tendências (pp. 3-13). Curitiba: Fundação O Boticário de Proteção à Natureza.

Pires, P. dos S. (2005). Capacidade de Carga como paradigma de gestão dos impactos da recreação e do turismo em áreas naturais. Turismo em Análise, 16 (1), pp. 5-28.

Presidência da República. Legislação (2007). Retrieved from http://www4.planalto.gov. $\mathrm{br} /$ legislacao

República Federativa do Brasil. Lei no 9.985, de 18 de julho de 2000. Regulamenta o art. 225, § 10, incisos I, II, III e VII da Constituição Federal, institui o Sistema Nacional de Unidades de Conservação da Natureza. Retrieved from http://www. presidencia.gov.br/CCIVIL_03/LEIS/ L9985.htm

Soawinski, R. J. (1997). Sistema nacional de unidades de conservação: legislação e política. In Congresso Brasileiro de Unidades de Conservação. Curitiba: IAP/ UNILIVRE/Rede Nacional Pró-Unidade de Conservação.

Takahashi, L. Y. (2002). Recursos humanos para o manejo das unidades de conservação: formação básica e capacitação no Brasil. In Milano, M. S. Unidades de conservação: atualidade e tendências (pp. 53-63). Curitiba: Fundação O Boticário de Proteção à Natureza.

Takahashi, L. Y. (2004). Uso público em unidades de conservação. Cadernos de Conservação 2(2). Curitiba: Fundação O Boticário de Proteção à Natureza. 
abordada. Atualmente a home page da ICMBio - Instituto Chico Mendes de Conservação da Biodiversidade disponibiliza diversos planos de manejo para consulta, facilitando assim, a ampliação do campo de pesquisa.

Enquanto não existirem ferramentas eficazes que garantam sua execução, o ator mais prejudicado do processo é a própria natureza. O Brasil possui parque onde esses mecanismos funcionam, porém, existem muitos outros em que, diariamente, são travadas batalhas ferozes de interesses de ambientalistas e sociedade civil. Cabe à academia continuar chamando a atenção da opinião pública para essas problemáticas.

\section{REFERÊNCIAS}

Ambiente Brasil. Plano de manejo de parques nacionais (2007). Disponível em: <ww. ambientebrasil.com.br>.

Azevedo, P. U. E. de. (2002). Implementando as unidades de conservação: particularidades da regularização fundiária. In Milano, M. S. Unidades de Conservação: atualidade e tendências (pp. 17-30) Curitiba: Fundação O Boticário de Proteção à Natureza.

Barros II, S. M. (1997). Turismo e unidades de conservação no Brasil. In Congresso Brasileiro de Unidades de Conservação (pp. 298-319). Curitiba: IAP/UNILIVRE/Rede Nacional Pró-Unidade de Conservação.

Eagles, P. F. J., Mccool, S. F., \& Haynes, C. D. (2002). Sustainable tourism in protected areas: guidelines for planning and management. Best Practice Protected Areas Guidelines Series (8). IUCN: The World Conservation Union.

Instituto Brasileiro do Meio Ambiente e dos Recursos Naturais Renováveis. Ibama. Roteiro metodológico de planejamento: Parque Nacional, Reserva Biológica, Estação Ecológica (2002a). Edições Ibama. Disponível em http://www.ibama.gov.br/ siucweb/unidades/roteiro_metodologico_ revisado_05_2005.pdf.

Instituto Brasileiro do Meio Ambiente e dos Recursos Naturais Renováveis. Ibama. Unidades de conservação - Parques Nacionais (Parque Nacional da Lagoa do Peixe). Plano de Manejo (2002b). Disponível em http://www.ibama.gov.br.

Kinker, S. (2002). Ecoturismo e conservação da natureza em parques nacionais. Campinas: Papirus.

Pádua, M. T. J. (2002). Unidades de Conservação: muito mais do que a criação e planos de manejo. In Milano, M. S.
Unidades de Conservação: atualidade e tendências (pp. 3-13). Curitiba: Fundação O Boticário de Proteção à Natureza.

Pires, P. dos S. (2005). Capacidade de Carga como paradigma de gestão dos impactos da recreação e do turismo em áreas naturais. Turismo em Análise, 16 (1), pp. 5-28.

Presidência da República. Legislação (2007). Disponível em: <http://www4.planalto. gov.br/legislacao>.

República Federativa do Brasil. Lei no 9.985, de 18 de julho de 2000. Regulamenta o art. 225, § 10, incisos I, II, III e VII da Constituição Federal, institui o Sistema Nacional de Unidades de Conservação da Natureza. Disponível em http://www. presidencia.gov.br/CCIVIL_03/LEIS/ L9985.htm.

Soawinski, R. J. (1997). Sistema nacional de unidades de conservação: legislação e política. In Congresso Brasileiro de Unidades de Conservação. Curitiba: IAP/ UNILIVRE/Rede Nacional Pró-Unidade de Conservação.

Takahashi, L. Y. (2002). Recursos humanos para o manejo das unidades de conservação: formação básica e capacitação no Brasil. In Milano, M. S. Unidades de conservação: atualidade e tendências (pp. 53-63). Curitiba: Fundação O Boticário de Proteção à Natureza.

Takahashi, L. Y. (2004). Uso público em unidades de conservação. Cadernos de Conservação 2(2). Curitiba: Fundação O Boticário de Proteção à Natureza. 


\section{APÊNDICES E/OU ANEXOS - APPENDICES}
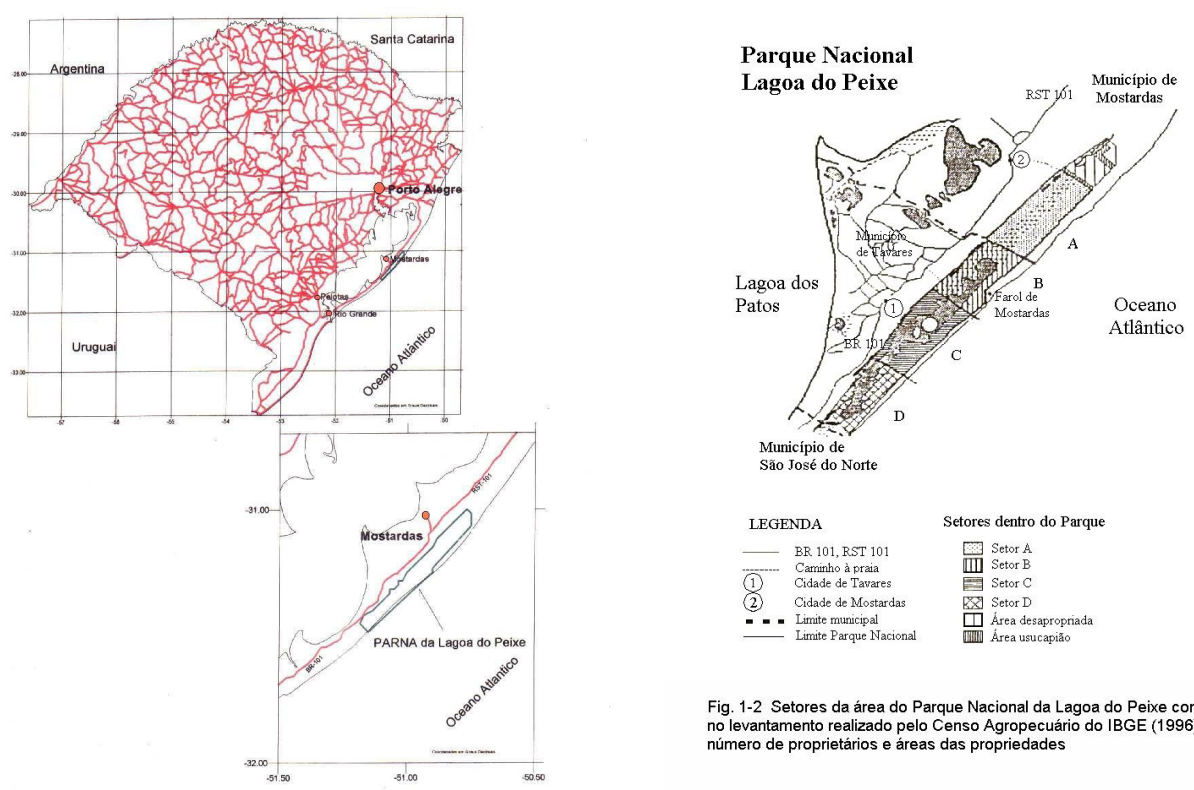

Fig. 1-2 Setores da área do Parque Nacional da Lagoa do Peixe considerados no levantamento realizado pelo Censo Agropecuário do IBGE (1996) do número de proprietários e áreas das propriedades

Figura 1-1 - Mapa do Estado do Rio Grande do Sul com a localizaçāo do Parque Nacional da Lagoa do Peixe e as estradas de acesso a Mostardas (Sede do Parque)

Figura 1: Localização do Parque Nacional da Lagoa do Peixe (RS). Fonte: Plano de Manejo Parque Nacional da Lagoa do Peixe - Ibama (2007)

Figure 1: Location of Lagoa do Peixe National Park (RS-Brazil). Source: National Park Management Plan for Fish Pond - Ibama (2007) 